\title{
PENERAPAN ASAS ERGA OMNES DALAM PUTUSAN MAHKAMAH KONSTITUSI NOMOR 30/PUU-XVI/2018 DIKAITKAN DENGAN ASAS NEGATIVE LEGISLATOR
}

\author{
Muchamad Lufti Hakim \\ (Mahasiswa Program S1 Fakultas Hukum Universitas Tarumanagara) \\ (E-mail: hakimlufti12@gmail.com)
}

\section{Rasji S.H.,M.H}

(Corresponding Author)

\begin{abstract}
(Dosen Fakultas Hukum Universitas Tarumanagara. Meraih Sarjana Hukum pada Fakultas Hukum
\end{abstract} Universitas Tarumanagara, Magister Hukum pada Fakultas Hukum Universitas Indonesia,

$$
\text { (E-mail: rasji@fh.untar.ac.id) }
$$

\begin{abstract}
The problem began because there was an Application to Judicial Review Article 182 Letter $l$ specifically in the phrase "other work" Law Number 7 of 2017. The applicant requested the Constitutional Court to interpret the phrase "other work". The request was finally granted by the Constitutional Court which interpreted the phrase "other work" in Article 182 letter lof the Act to also serve as a Political Party Functionary. For the Decision, there are Parties who disagree, finally the KPU Regulation Number 26 Year 2018 which accommodates the MK Decision so that candidates for DPD members resign from Political Parties to the Administrative Court and MA. The problem is that the Decision of the Administrative Court and Supreme Court is different from the Constitutional Court Decision, both decisions allow political party functionaries to register as candidates for the DPD. In solving these problems the author uses the Normative Legal Research Method, the author's conclusion is that the principle of the Erga Omnes and the principle of the Negative legislator attached to the Constitutional Court Decision is not effective. While the author's suggestion is that there is a need for a revision of the Constitutional Court Law by adding sanctions to institutions or communities that do not follow the MK Decision.
\end{abstract}

Keywords: Mahkamah Konstitusi, erga omnes, negative legislator 


\section{Pendahuluan}

\section{A. Latar Belakang}

Dinamika kelembagaan Negara mengalami turbulensi politik dan hukum yang cukup eskalatif disemua segmen kehidupan. Dari awal era reformasi Majelis Permusyawaratan Rakyat (MPR) telah berhasil melakukan proses amandemen sebanyak empat kali terhadap Undangg-Undangg Dasar Negara Kesatuan Republik Indonesia Tahun 1945 (UUD 1945). Langkah amandemen ditempuh guna memenuhi tuntutan reformasi demi memperbaiki sistem ketatanegaraan yang lebih demokratis dan berkeadilan.

Sebelum dilakukan amandemen UUD 1945, Negara hanya mengenal lima Lembaga negara seperti yang ada dalam UUD 1945 sebagaimana juga dimaksudkan oleh Tap MPR No.III/MPR/1978 yaitu, Majelis Permusyawaratan Rakyat (MPR), Presiden, Dewan Perwakilan Rakyat (DPR), Badan Pemeriksa Keuangan (BPK), Dewan Pertimbangan Presiden (DPA), dan Mahkamah Agung (MA). ${ }^{1}$

Dalam kenyataannya bahwa UUD 1945 sebelum amandemen selalu menimbulkan ketidak pastian hukum. Ini dapat di lihat dari periode berlakunya UUD 1945 yang berlaku dalam tiga periode sejarah politik dan ketatanegaraan Indonesia, yaitu pertama, Periode 1945-1949; kedua, Periode 1959-1966; ketiga, Periode 1966-1998. ${ }^{2}$ Alasan mengapa pada periode berlakunya UUD 1945 yang asli selalu terjadi otoriterisme, berbagai studi telah menyimpulkan bahwa UUD 1945 mengandung kelemahan sistem yang dijadikan pintu masuk untuk membangun otoriterisme. ${ }^{3}$ Akibat terjadinya otoriterisme akhirnya kehidupan bernegara menjadi sentralistik yang

\footnotetext{
${ }^{1}$ Khelda Ayunita dan Abd. Rais Asman, Hukum Tata Negara Indonesia. (Jakarta: Mitra Wacana Media, 2016), hal. Xi.

${ }^{2}$ Mahfud MD, Konstitusi dan Hukum dalam Kotroversi Isu. (Jakarta: PT RajaGrafindo Persada, 2009), hal. 139.

${ }^{3}$ Ibid. hal 142
} 
menyebabkan daerah daerah merasa tidak tersampaikan aspirasinya kepada pusat.

Setelah adanya Amandemen Dasar Negara, tampak jelas bahwa kehidupan demokrasi tumbuh dengan baik. Dilakukannya perubahan itu sendiri sudah merupakan kebaikan yang sangat besar bagi demokrasi kita sebab pada masa lalu jika ada gagasan untuk mengubah UUD 1945 sangat di tabukan. Perubahan yang sangat jelas pada amandemen UUD 1945 yaitu pada lembaga-lembaga negara salah satunya MPR, MPR bukanlah lembaga tertinggi negara melainkan menjadi lembaga negara yang sederajat lembagalembaga lain. Selain itu, MPR pada amandemen UUD 1945 Pasall 2 ayat (1) tercantum bahwa MPR merupakan DPR dan DPD. Keberadaan DPD dalam amandemen UUD 1945 dengan penuh harapan bahwa aspirasi-aspirasi daerah bisa di sampaikan kepada pemerintah pusat melalui DPD.

Kedudukan DPD sudah di atur dalam Pasall 22C UUD 1945 yang menyebutkan dengan tegas bahwa DPD dipilih dari masing-masing provinsi dengan pemilihan umum, dan kewenangan dari DPD dijabarkan pada Pasall 22D UUD 1945 yang mengatakan bahwa DPD bisa mengajukan Rancangan undang-undang kepada DPR yang berkaitan otonomi daerah, hubungan pusat dan daerah, pembentukan, pemekaran dan penggabungan daerah, pengelolaan sumber daya alam dan sumber daya ekonomi lainnya serta yang berkaitan dengan daerah lainnya.

Tercantum dalam Undang-Undang Nomor 17 tahun 2014 Tentang Majelis Permusyawaratan Rakyat, Dewan Perwakilan Rakyat, Dewan Perwakilan Daerah dan Dewan Perwakilan Rakyat Daerah Pasall 246 dikatakan DPD terdiri atas daerah Provinsi yang di pilih as1smelalui pemilihan Umum, dan pada Pasal 247 di jabarkan tugas dan wewenang DPD sebagai perpanjangan tangan Daerah kepada pemerintah pusat. Wewenang dan tugas DPD diperkuat dengan Undang-undang Nomor 2 Tahun 2018 tentang Perubahan atas Undang-Undang Nomor 17 Tahun 2017 tentang Majelis Permusyawaratan 
Rakyat, Dewan Perwakilan Rakyat, Dewan Perwakilan Daerah dan Dewan Perwakilan Rakyat Daerah pada Pasal 249 dicantumkan DPD merupakan Lembaga perwakillan di daerah yang berkedudukan sebagai Lembaga Negara. Berdasarkan Undang-undangg Dasar dan Undang-undangg tersebut di syaratkan bahwa anggota DPD terdiri dari utusan daerah yang merepresentasikan aspirasi dari masyarakat daerah. Keterwakilan di daerah diharapkan agar terhindarnya monopoli pembuatan Undang-Undangg, sehingga undang-undangg yang dihasilkan oleh lembaga legislatife menjadi lebih terarah dan sempurna. Dengan adanya kamar bikameral ini maka akan terbentuk mekanisme saling cek dua Lembaga legislatif antara DPD yang mewakili kedaerahan serta DPR yang mewakili kepentingan Partai karena berasal dari partai politik.

Cita cita demokrasi dan amandemen UUD 1945 yang menginginkan DPD menjadi lembaga yang bersumber dari daerah agaknya mulai luntur, Pasalnya banyak kader kader partai politik mencalonkan diri untuk menjadi "Second Camber” ini. Melalui data Indonesian Parliamentary Center di katakan hingga akhir tahun 2017 ada 78 dari 132 anggota DPD yang merupakan Partai Politik.

Atas data tersebut, yang terbanyak adalah berasal dari Partai Hanura (28 orang), Partai Golkarr (14 orang), Partai Persatuan Pembangunan atau PPP (8 orang), Partai Keadillan Sejahtera atau PKS (6 orang), dan Partai Amanat Nasional (PAN). ${ }^{4}$ Dalam data tersebut menunjukan bahwa lebih dari $50 \%$ dari seluruh anggota DPD berasal dari Partai dan hal itu menciderai marwah DPD yang merupakan utusan dari daerah untuk menyampaikan aspirasi daerah ke tingkat pemerintahan pusat.

\footnotetext{
${ }^{4}$ Anonim, "Poin Penting dari Putusan MK larang pengurus parpol jadi anggota DPD", https://nasional.kompas.com/read/2018/07/24/08553721/5-poin-penting-dari-putusan-mk-larangpengurus-parpol-jadi-anggota-dpd?page=all diunduh pada tanggal 27 Juli 2018 pukul 09.36 WIB.
} 
Celah masuknya anggota partai politik ada pada Undang-Undang No 7 Tahun 2017 tentangg Pemilihan Umum yang menghilangkan syarat agar peseta pemilu mengundurkan diri dari partai politik. Dalam Pasal 182 huruf I dikatakan bahwa "Bersedia untuk tidak berpraktik pada akuntan publik, notaris, pejabat pembuat akta tanah, dan/atau tidak melakukan pekerjaan penyedia barang dan jasa yang berhubungan dengan keungan negara serta pekerjaan lain yang berhubungan dengan keuangan negara serta pekerjaan lain yang dapat menimpulkan konflik kepentingan dengan tugas, wewenang, dan hak sebagai angoota DPD sesuai dengan ketentuan peraturan perundangundangan".

Sebelumnya, dalam Undang-Undangg Nomor 12 Tahun 2003 tentang Pemilu anggota Majelis Permusyawaratan Rakyat, Dewan Perwakilan Rakyat, Dewan Perwakilan Daerah dan Dewan Perwakilan Rakyat Daerah Pasal 63B mengamanatkan gamblang jelas bahwa Calon Anggota DPD harus mengundurkan diri dari Partai Politik Minimal 4 Tahun sebelum dia mendaftar menjadi anggota DPD. Politik Hukum yang terjadi terhadap syarat Calon anggota DPD ini menjadikan marwah DPD sebagai utusan lokal untuk membawa aspirasi dari Daerah ketingkat Pusat menjadi menghilang.

Pada tanggal 4 April 2018 Muhammad Hafidz yang juga merupakan Peserta Pemilu tahun 2014 dan akan mencalonkan diri kembali sebagai Anggota DPD dari jalur Independen dan bukan dari partai politik mengajukan Permohonan "Judicial Review" ke Mahkamah Konstitusi ${ }^{5}$ atas Pasal 182 huruf 1 Undang-undang Nomor 7 tahun 2017, bahwa Muhammad Hafidz hendak mengajukan pengujian norma pada frasa Pekerjaan Lain pada Pasal 182 huruf I Undang-undang tersebut. Menurutnya yang di tuangkan dalam "Legal Standing" dari permohonanya dikatakan bahwa dengan tidak adanya pemaknaan yang jelas dan terang menderang sepanjang frasa "Pekerjaan lain"

${ }^{5}$ Mahkamah Konstitusi, Putusan Mahkamah Konstitusi Nomor 30/PUU-XVI/2018 
Pada Pasal 182 Huruf I tersebut telah memberikan kemungkinan bagi pengurus partai politik untuk ikut serta dalam pemilu sebagai calon perseorangan DPD. Sehingga Muhammad Hafidz merasa tidak adanya kepastian hukum sepanjang representasi DPD sebagai perwakilan dari masyarakat lokal untuk mewakili daerah yang bebas dari kepentingan partai politik. Atas permohonan itu Mahkamah Konstitusi telah memutus pada sidang pleno pada hari Senin tanggal 23 Juli 2018 dengaan Nomor Register putusan Nomor 30/PUU-XVI/2018 dengan amar yaitut :

1. Mengabulkan Permohonan Pemohon untuk seluruhnya;

2. Frasa "Pekerjaan lain" dalam Pasall 182 huruf I Undang-Undang Nomor 7 Tahun 2017 tentang Pemilihan Umum bertentangan dengan UUD 1945 dan tidak mempunyai kekuatan huukum mengikat secara bersyarat sepanjang tidak dimaknai mencakup pula pengurus (fungsionaris) partai politik;

3. Memerintahkan pemuatan putusan ini dalam Berita Negara Republik Indonesia sebagaimana mestinya.

Dalam pertimbangan hukumnya Mahkamah Konstitusi memerintahkan KPU melarang fungsionaris partai menjadi calon DPD dalam Pemilu 2019. Atas Putusan mahkamah Konstitusi tersebut banyak kritikan terhadap putusan Mahkamah Konstitusi Nomor 30/PUU-XVI/2018 salah satunya yaitu wakil ketua DPD Nono Sampono yang menyurati Komisi Pemilihan Umum (KPU) dalam surat tersebut DPD menyimpulkan adanya sejumlah kejanggalan dari putusan MK tersebut, salah satunya karena putusan MK melahirkan syarat baru bagi calon anggota DPD ketika proses pendaftaran, kemudian verifikasi, dan pengumuman hasil verifikasi ${ }^{6}$ karena seharusnya Putusan Mahkamah Konstitusi tidak menimbulkan norma baru .

${ }^{6}$ Anonim, "DPD Menyurati KPU bela Osman Sapta Odang", https://rumahpemilu.org/dpdmenyurati-kpu-bela-oesman-sapta-odang. Diunduh pada hari selasa tanggal 25 September 2018 pukul 23.04 WIB 
Masalah lain yang timbul dari adanya putusan Mahkamah Konstitusi ini yaitu bahwa tidak semua calon anggota DPD mau melaksanakan putusan ini, padahal Putusan Mahkamah Konstitusi bersifat erga omnes yaitu putusan yang dimaksud tidak hanya mengikat bagi pihak yang mengajukan perkara di MK, melainkan mengikat juga semua warga masyarakat. ${ }^{7}$ salah satu contohnya yaitu calon anggota DPD Osman Sapta Odang menggugat KPU ke Badan Pengawas Pemilu (BAWASLU) karena di coret oleh KPU dari daftar calon tetap. ${ }^{8}$ Disisi lain KPU memberikan alternatif bagi calon anggota DPD yaitu bisa pindah mencalonkan diri ke DPR atau mengundurkan diri dari partai politik.

Pada dasarnya asas erga omnes ini untuk memberikan kepastian hukum, namun pada faktanya putusan Mahkamah Konstitusi tersebut tidak diterima dengan baik dan di jalankan oleh para calon anggota DPD tersebut.

Dalam keputusan sidang ajudikasi BAWASLU memenangkan KPU sebagai termohon dengan amar "Memutus terlapor (KPU) tidak terbukti secara sah dan meyakinkan melakukan pelanggaran administrasi”. Dengan demikian Osman Sapta Odang dinyatakan tidak lolos dalam Pemilihan Umum DPD tahun 2019. Atas keputusan BAWASLU tersebut kuasa hukum Osman Sapta Odang akan menggugat kembali KPU melalui Peradilan Tata Usaha Negara.

Terhadap fakta fakta tersebut menarik untuk dikaji putusan Mahkamah Konstitusi Nomor 30/PUU-XVI/2018 tersebut karena ada 2 (dua) masalah dalam putusan Mahkamah Konstitusi tersebut pertama dalam putusan tersebut Mahkamah Konstitusi memberikan norma baru yaitu memperluas frasa

\footnotetext{
${ }^{7}$ Anonim, “ Ratio Decidendi Dari Putusan MK yang memutuskan penyelenggaraan pemilu serentak padahal sebelumnya diputus sebaliknya", http://repository.unair.ac.id/13750/13/13.\%20Bab\%203.pdf. Diunduh pada hari selasa tanggal 25 bulan September 2018 pukul 23.05

${ }^{8}$ Anonim, "dicoret dari daftar calon tetap oso gugat keputusan KPU”, https://nasional.kompas.com/read/2018/09/20/20184821/dicoret-dari-daftar-calon-tetap-oso-gugatkeputusan-kpu. Diunduh pada hari selasa tanggal 25 bulan September 2018 pukul 23.13
} 
"pekerjaan lain" dengan melarang fungsionaris partai politik untuk menjadi anggota DPD, padahal sifat dari putusan Mahkamah Konstitusi yaitu negatif legislatur yaitu Mahkamah Konstitusi tidak boleh memberikan norm baru dalam putusannya, kedua bahwa putusan tersebut tidak serta merta diikuti oleh beberapa calon anggota DPD dan malah memilih untuk mempersoalkan putusan tersebut. Ini menunjukan bahwa asas erga omnes dalam Putusan Mahkamah Konstitusi belum dijalankan secara optimal. Berdasarkan uraian tersebut di atas, judul penulisan proposal ini adalah "Penerapan Asas Erga Omnes pada Putusan Mahkamah Konstitusi Nomor 30/PUU-XVI/2018 Dikaitkan dengan Asas Negative Legislator".

\section{B. Perumusan Masalah}

Sebuah penelitian hukum pasti bertujuan untuk menjawab isu hukum yang ada. Oleh karena itu permasalahan yang akan dijawab oleh penelitian ini adalah Bagaimana penerapan asas erga omnes dalam putusan Mahkamah Konstitusi Nomor 30/PUU-XVI/2018 dikaitkan dengan asas negative legislator?

\section{Pembahasan}

Penulis melakukan penelitian ini dengan mengangkat permasalahan mengenai bagaimana penerapan asas erga omnes dalam putusan Mahkamah Konstitusi Nomor 30/PUU-XVI/2018 dikaitkan dengan asas negative legislator. Seiring berjalannya penelitian Penulis, berdasarkan data dan teori yang Penulis dapatkan, ada beberapa hal yang Penulis analisa dan akan Penulis paparkan dalam penulisan bab ini.

\section{A. Uji Materil Undang-Undang Nomor 7 Tahun 2017 tentang Pemilihan Umum terhadap Undang-Undang Dasar Negara Republik Indonesia Tahun 1945 (Putusan Nomor 30/PUU-XVI/2018)}

Undang-Undang Nomor 7 tahun 2017 tentang Pemilihan Umum merupakan dasar bagi penyelenggaraan Pemilu tahun 2019 yang akan datang. Pada Pasal 182 Huruf I Undang-Undang a quo disebutkan bahwa Bersedia untuk tidak berpraktek 
pada akuntan publik, notaris, pejabat pembuat akta tanah, dan/atau tidak melakukan pekerjaan penyedia barang dan jasa yang berhubungan dengan keungan negara serta pekerjaan lain yang berhubungan dengan keuangan negara serta pekerjaan lain yang dapat menimpulkan konflik kepentingan dengan tugas, wewenang, dan hak sebagai angoota DPD sesuai dengan ketentuan peraturan perundang-undanggan. Pasal tersebut dianggap menyimpang dari Original Intent DPD karena tidak secara jelas melarang fungsionaris Partai Politik untuk mencalonkan diri menjadi anggota DPD. Berbeda pada Undang-Undang Nomor 12 Tahun 2003 tentang Pemilu MPR, DPR, DPD dan DPRD dijelaskan pada Pasall 63B secara jelas fungsionaris Partai Politik yang ingin mencalonkan diri menjadi anggota DPD harus mengundurkan diri minimal 4 tahun sebelum dia mendaftar menjadi anggota DPD. Atas dasar tersebut Undang-Undang ini di ajukan permohonan Uji Materil ke Mahkamah Konstitusi.

Permohonan Uji Materil Undang-Undang Nomor 7 tahun 2017 Tentang Pemilu di ajukan oleh Muhammad Hafidz (Pemohon) pada tanggal 4 April 2018 yang di terima Kepaniteraan Mahkamah Konstitusi pada tanggaal 4 April 2018 berdasarkan akta penerimaan berkas perkara nomor 59/PAN.MK/2018 dan telah dicatat dalam Buku Register Perkara Konstitusi pada tanggal 9 April 2018 dengan nomor 30/PUU-XVI/2018. Setelah itu pemohon diminta untuk memperbaiki permohonan tersebut dan telah diperbaiki dengan perbaikan permohonan tertanggal 19 April 2018 dan diterima Kepaniteraan Mahkamah Konstitusi pada tanggal 19 April 2018.

Dalam pertimbangannya, Majelis Hakim Konstitusi mengatakan bahwa gagasan untuk lebih meningkatkan akomodasi terhadap aspirasi daerah yang diejawantakan dengan membentuk DPD tersebut akan terwujud apabila aspirasi daerah itu tercermin dalam keputusan politik yang diambil di tingkat nasional, khususnya dalam kebijakan legislasi, in casu pembentukan Undang-Undang sebagai penjabaran lebih lanjut dari gagasan yang tertuang dalam UUD 1945 yang berkaitan dengan kepentingan daerah. Sebelumnya dalam putusan Mahkamah 
Konstitusi Nomor 10/PUU-VI/2008 pertimbangan hukumnya Majelis Hakim Konstitusi menyebutkan antara lain "amandemen UUD 1945 melahirkan Lembaga baru dalam struktur kenegaraan Indonesia, yakni DPD yang dengan kehadirannya sistem perwakilan di Indonesia, DPR didukung dan diperkuat oleh DPD. DPR merupakan Lembaga perwakilan berdasarkan aspirasi dan paham politik rakyat sebagai pemegang kedaulatan, sedangkan DPD merupakan Lembaga perwakilan penyalur keanekaragaman aspirasi daerah.

Secara analitis, original intent pembentukan DPD maupun pertimbangan Mahkamah dalam putusan tersebut memiliki lamdasan rasional-faktual maupun konsepsional yang kuat. Pertama, dilihat dari perspektif fungsi-fungsi ideal partai politik, original intent pembentukan DPD dan putusan Mahakamah Konstitusi tersebut tidak dapat dinilai menafikan fungsi-fungsi ideal partai politik, khususnya dalam ha lini fungsi agregasi dan komunikasi politik.

Kedua, persyaratan anggota DPD tidak boleh menjadi anggota partai politik mencegah terjadi distorsi politik berupa lahirnya perwakilan ganda (double representasion) partai politik dalam mengambil keputusan. Desain tersebut merupakan hal mendasar karena secara filosofis diturunkan dari gagasan kebangsaan Indonesia yang bukan sekedar ikatan persatuan politik yang lahir karena adanaya persamaan nasib dari sebenap suku bangsa yang mendiami wilayah yang bernama Indonesia tetapi juga mencakup gagasan persatuan segenap suku bangsa dimaksud dengan wilayah yang dinamainya itu.

Ketiga, alasan mencegah terjadinya double representation inilah, Bersamasama dengan alasan untuk menerapkan prinsip perwakilan atas dasar pemilihan, yang dijadikan dasar argumentasi menolak adanya anggota MPR yang pengisiannya dilakukan dalam mekanisme pengangkatan, dalam hal ini dikaitkan dengan adanya Utusan Golongan. Sejak putusan pertamanya yang berkaitan dengan keanggota DPD, yaitu Putusan Mahakamah Konstitusi Nomor 10/PUUVI/2008 Mahkamah Secara Konsisten menunjukan pendiriannya dalam menjaga hakikat keberadaan DPD sesuai dengan UUD 1945. 
Untuk pemilu Tahun 2019, karena masa daftaran calon anggota DPD sudah dimulai, jika terdapat calon anggota DPD yang merupakan pengurus parpol terkena imbas dari putusan ini, maka mahkamah memberikan kewenangan kepada KPU untuk dapat diberikan kesempatan kepada yang calon tersebut untuk tetap sebagai bakal calon anggota DPD sepanjang telah menyatakan pengundurandiri dari parpol dengan bukti pernyataan tertulis yang bernilai hukum perihal pengunduran diri yang dimaksud. Dengan demikian untuk selanjutnya anggota DPD sejak pemilu 2019 yang menjadi pengurus Parpol dinyatakan pertentangan dengan UUD 1945.

\section{B. Putusan Mahkamah Agung Nomor 65P/HUM/2018 Tentang Uji Materil Peraturan KPU Nomor 26 Tahun 2018 Tentang Perubahan Kedua Atas Peraturan KPU Nomor 14 Tahun 2018 Tentang Pencalonan Perseorangan Peserta Pemilu Anggota DPD}

Menurut Mahkamah Agung tindakan KPU mengeluarkan Peraturan KPU Nomor 26 Tahun 2018 sebagai tindak lanjut dari Putusan Mahkamah Konstitusi adalah tindakan yang beralasan menurut hukum, mengingat kedudukan Putusan Mahkamah Konstitusi adalah sederajat dengan Undang-Undang. Bahwa keadaan yang demikian, seolah-olah membenturkan Mahkamah Agung dengan Mahkamah Konstitusi, karena pada satu sisi Termohon menjalankan Putusan Mahkamah Konstitusi dan pada sisi yang lain Pemohon merasa dirugikan dengan peraturan yang diberlakukan secara surut (retroaktif), dan pada saat yang sama Mahkamah Agung pun tidak boleh menolak untuk memeriksa, mengadili, dan memutus suatu perkara yang diajukan dengan dalih bahwa hukum tidak ada atau kurang jelas, melainkan wajib untuk memeriksa dan mengadilinya. Oleh karena itu, persoalan utama yang harus dijawab dalam permohonan Hak Uji materil ini menurut Mahkamah adalah konflik antara norma hukum berupa putusan Mahkamah Konstitusi yang kedudukannya sederajat dengan undang-undang dengan asas hukum berupa asas non retroactive yaitu suatu asas yang menekankan bahwa suatu peraturan perundang-undangan tidak boleh diberlakukan surut ke belakang. 
Meskipun telah nyata Putusan Mahkamah memperoleh kekuatan hukum mengikat terhitung sejak diucapkan, namun ternyata pihak Termohon tetap memberlakukan Ketentuan Pasal 60A Peraturan KPU Nomor 26 Tahun 2018 secara surut (retroactive) terhadap calon Anggota Dewan Perwakilan Daerah Tahun 2019, dengan dalih pelaksanaan Putusan Mahkamah Konstitusi. Terhadap hal demikian, menurut Mahkamah penerapan peraturan a quo tersebut tidak efektif, karena perubahan suatu aturan disertai dengan suatu kewajiban (yang sebelumnya belum diatur) pada saat tahapan, program, dan penyelenggaran pemilu Anggota Dewan Perwakilan Daerah Tahun 2019 yang telah dilaksanakan dan sedang berlangsung dapat menimbulkan persoalan hukum baru. Hal ini akan berbeda keadaannya jika Putusan Mahkamah Konstitusi lebih dulu diputus (dan kemudian diikuti dengan pembuatan peraturan KPU) dibandingkan dengan pelaksanaan tahapan, program, dan penyelenggaran pemilu Anggota Dewan Perwakilan Daerah Tahun 2019 tersebut. Oleh sebab itu dibutuhkan kebijaksanaan para penyelenggara pemilu dalam memecahkan persoalan-persoalan hukum demi menjamin selaras dan kepastian hukum serta pemilihan umum yang efektif dan efisien.

Untuk memberikan kepastian hukum Mahkamah Agung Berpendapat terhadap Pelaksanaan tahapan, program, dan penyelenggaran pemilu 2019, khususnya menyangkut Pemilihan Umum Anggota Dewan Perwakilan Daerah Tahun 2019, Mahkamah merasa perlu membatasi akibat hukum yang timbul dari Putusan Hak Uji Materil sepanjang menyangkut kekuatan hukum mengikat Ketentuan Pasal 60A Peraturan KPU Nomor 26 Tahun 2018. Mahkamah berpendapat, Ketentuan Pasal 60A Peraturan KPU Nomor 26 Tahun 2018 yang telah dinyatakan bertentangan dengan ketentuan Pasall 5 huruf d dan Pasal 6 ayat (l) huruf i Undang-Undang Nomor 12 Tahun 2011 tentang Pembentukan Peraturan Perundang-Undangan, tetap mempunyai kekuatan hukum mengikat sepanjang tidak diberlakukan surut terhadap Peserta Pemilu Anggota Dewan Perwakilan Daerah Tahun 2019 yang telah mengikuti Tahapan, Program dan Jadwal 
Penyelenggaraan Pemilihan Umum 2019 berdasarkan Peraturan KPU Nomor 7 tahun 2017. Hal demikian dimaksudkan agar adanya kepastian hukum terhadap Peserta Pemilu Anggota Dewan Perwakilan Daerah Tahun 2019, sekaligus untuk menjamin Tahapan, Program dan penyelenggaraan Pemilu Umum Tahun 2019 dapat berjalan dengan baik tidak terganggu oleh gugatan dari pihak-pihak yang menganggap hak-hak hukumnya dirugikan oleh berlakunya Peraturan KPU Nomor 26 Tahun 2018.

\section{Mahkamah Konstitusi dan Asas Erga Omnes}

Asas erga omnes dan asas negative legislator merupakan dua asas yang melekat pada setiap Putusan MK, pengertian dari asas erga omnes sendiri yaitu bahwa setiap Putusan MK berlaku bukan hanya bagi para pihak yang berperkara melainkan bagi seluruh rakyat Indonesia. Asas erga omnes pada dasarnya untuk memberikan kepastian hukum terhadap Putusan Mahkamah Konstitusi. Berbeda dengan asas erga omnes, asas negative legislator adalah bahwa Putusan MK tidaklah boleh mengandung Norma baru hal ini tertuang dalam UndangggUndangg Nomor 8 Tahun 2011 tentang peruahan Undang-Undang Nomor 24 Tahun 2003 tentang Mahkamah Konstitusi pada Pasal 57 ayat (2) yang menjelaskan secara normatif bagaimana seharusnya Putusan MK.

Seperti Badan Pengadilan pada umumnya, Mahkamah mengeluarkan putusan. Perbedaan yang sangat mendasar antara putusan yang dikeluarkan oleh MK dengan institusi peradilan lainnya yaitu mengenai upaya hukum lanjutan atas putusannya. kalau putusan yang dikeluarkan oleh badan pengadilan lainnya seperti Mahkamah Agung dan peradilan di bawahnya dapat dilakukan upaya hukum lanjutan jika tidak puas dengan putusannya, baik berupa banding ke pengadilan Tinggi, kasasi ke Mahkamah Agung, maupun peninjauan kembali atas bukti baru. putusan MK tidak ada upaya hukum tersebut. Dikatakan di dalam konstitusi bahwa MK merupakan peradilan tingkat pertama dan terakhir yang putusannya bersifat final dan mengikat. Ditegaskan kembali di dalam Pasal 10 Undangg-Undangg Nomor 8 Tahun 2011 tentang Perubahan Atas Undang-Undang Nomor 24 Tahun 
2003 tentang Mahkamah Konstitusi (Undang-Undang MK) bahwa makna Putusan final, putusan MK juga mencakup di dalamnya kekuatan mengikat. Artinya, putusan MK dapat langsung memperoleh kekuatan hukum tetap sejak diucapkan dan tidak dapat ada upaya hukum yang dapat ditempuh sebagai langkah keberatan dari Putusan MK.

Permasalahan kemudian muncul ketika putusan MK harus membutuhkan tindak lanjut untuk mengamalkannya, dan menjadikan lembaga lain untuk mengamalkan putusan tersebut. Faktanya, kekuatan final dan mengikat putusan MK tidak dapat dilaksanakan secara konkret (non-excutiable) dan hanya mengawang (floating execution). Terdapat beberapa Putusan MK yang tidak dijalankan oleh Lembaga Yudikatif, Legislatif maupun Eksekutif. Putusan MK yang tidak dijalankan oleh cabangYudikatif yaitu MA misalnya, tidak menjalankan Putusan Nomor 34/PUU-XI/2013 yang membatalkan Pasal 268 ayat (3) KUHAP. Akibatnya dari putusan tersebut yaitu bahwa Peninjauan Kembali (PK) dapat diajukan oleh terpidana atau ahli warisnya lebih dari satu kali selama memenuhi persyaratan yang dituangkan dalam Pasal 268 ayat (2) KUHAP. Putusan MK ini kemudian dianulir oleh MA melalui Surat Edaran Mahkamah Agung (SEMA) Nomor 07 Tahun 2014 tentang Pengajuan Permohonan PK Dalam Pidana. Substansi dari SEMA tersebut adalah untuk menegaskan bahwa PK hanya dapat dilakukan 1 (satu) kali. Putusan MK yang tidak dilaksanakan oleh cabang kekuasaan eksekutif secara konsekuen yaitu Putusan Nomor 5/PUU-X/2012 tentang pengujian Pasal 50 ayat (3) Undang-Undang Nomor 20 Tahun 2003 tentang sisdiknas. Persoalan implementasi putusan MK pada konteks ini yaitu pemerintah dari Kementerian Pendidikan dan Kebudayaan masih menempuh kebijaksanaan masa transiisi untuk menghapus kebijakaan Sekolah Bertaraf Internasional (SBI) dan/atau Rintisan Sekolah Bertaraf Internasional (RSBI).5 Padahal Pokoknya, Putusan MK tidak ada masa transisi bagi dilaksanakan, namun mempunyai kekuatan hukum mengikat sejak diucapkan, yang artinya sejak saat itu pula harus dipatuhi dan diimplementasikan. Putusan yang tidak dilaksanakan oleh 
cabang lembaga legislatif misalnya adalah Putusan Nomor 011/PUU-III/2005 yang menyatakan bahwa penjelasan Pasal 49 ayat (1) Undang-Undangg Sistem Pendidikan Nasional (UU Sisdiknas) tidak mempunyai kekuatan hukum mengikat. Pada putusan tersebut MK berpendapat bahwa pada dasarnya pelaksanaan konstitusi tidak boleh ditundatunda, termasuk ketentuan anggaran minimal 20 persen dari APBN untuk pendidikan telah dinyatakan secara expres verbis, sehingga tidak boleh tafsir oleh peraturan perundang-undanggan di bawahnya. Namun, pada undang-undang yang lain yaitu Undang-Undang tentang APBN Tahun 2005 panitia anggaran DPR hanya mengalokasikan anggaran sebesar 36 Triliun atau setara dengan 8,1 persen dari total anggaran yang ada.

Dinamika dalam Putusan MK pada faktanya tidak sesuai dengan asas dan norma yang berlaku, seperti halnya juga pada Putusan Mahkamah Konstitusi Nomor 30/PUU-XVI/2018 ini yang menguji Undang-Undangg Nomor 7 Tahun 2017 Tentang Pemilihan Umum terhadap Undang-Undang Dasar. Putusan tersebut pada salah satu amar putusannya mengatakan bahwa kata "pekerjaan lain" dalam Pasal 182 huruf 1 Undang-Undang Nomor 7 Tahun 2017 tentang Pemilihan Umum berlawanan dengan UUD 1945 dan tidak mempunyai kekuatan hukum mengikat secara bersyarat sepanjang tidak dimaknai mencakup pula (fungsionaris) partai Politik. Pada mulanya Komisi Pemilihan Umum mengikuti Putusan tersebut dengan merubah Peraturan KPU nomor 14 Tahun 2018 menjadi Peraturan KPU nomor 26 Tahun 2018 karena pada Peraturan KPU yang lama tidak memuat syarat calon anggota DPD harus mengundurkan diri dari Partai Politik sebagaimana Putusan MK. Menurut Teori jenjang norma keputusan KPU ini sudah tepat namun banyak pihak yang menyayangkan Putusan MK dan keputusan KPU tersebut kerena Putusan MK diputus ketika masa pendaftaran calon anggota legislatif sedang berlangsung sehingga berujung tidak dilaksanakannya putusan ini oleh seluruh calon anggota DPD.

Atas uraian di atas penulis berpendapat bahwa penerapan asas erga omnes dalam Putusan Mahkamah Konstitusi Nomor 30/PUU-XVI/2018 tidak berjalan 
secara optimal dikarenakan Putusan tersebut belum sepenuhnya dapat diterima oleh masyarakat sebagaimana kekuatan hukum mengikat dari Putusan MK.

\section{Mahkamah Konstitusi dan asas Negative Legislator}

Sebelum adanya Undang-Undang MK, Mahkamah Konstitusi mengeluarkan Putusan-Putusan yang di anggap melanggar konstitusi atau keluar dari wewenang yang telah ada dalam Undang-Undangg Dasar Negara Kesatuan Republik Indonesia Tahun 1945 yaitu ultra petita juga sering disebut sebagai putusan yang bersifat positif. Sebagai contoh putusan Mahkamah Konstitusi dengan Nomor perkara: 102/PUU-VII/2009 (Penggunaan KTP) berkaitan dengan dibolehkannya KTP sebagai identitas pemilih pada Pemilu Presiden dan Wakil Presiden Tahun 2009. Putusan Mahkamah tersebut menimbulkan suatu keadaan hukum baru yaitu diperbolehkannya penggunaan KTP sebagai syarat untuk menjadi pemilih dan putusan ini tidak hanya berdampak pada para pihak yang berperkara saja (interpartes) melainkan seluruh warga negara Indonesia.

Sebagaimana Putusan MK juga terikat dengan asas negative legislator, dimana Putusan MK tidaklah boleh membuat norma baru dalam Putusannya. Seperti pada pasal 57 ayat (1) Undang-Undang Mahkamah Konstitusi menjelaskan bahwa Putusan MK menyatakan bahwa materi muatan ayat, pasal, dan/atau bagian Undang-Undang bertentangan dengan Undang-Undang Dasar Tahun 1945, materi muatan ayat, pasal dan/atau bagian dari Undang-Undang tersebut tidak mempunyai kekuatan hukum mengikat. Selain itu dalam Pasal 57 ayat (2a) dikatakan pula bahwa Putusan Mahkamah Konstitusi tidak memuat amar selain sebagaimana pada ayat (1) dan ayat (2), perintah kepada pembuat UndangUndang, dan rumusan norma sebagai pengganti norma dari Undang-Undang yang dinyatakan bertentangan dengan Undang-Undang Dasar Tahun 1945. Atas dasar hukum tersebutlah Putusan Mahkamah Konstitusi melanggar asas Negative Legislator karena menafsirkan frasa "pekerjaan lain" dalam Pasal 182 huruf 1 tersebut menjadi sepanjang "fungsionaris partai politik maka bertentangan dengan Undang-Undang Dasar”. 
Menyoroti terkait dengan asas negative legislator dalam putusan Mahkamah Konstitusi. Pihak yang menolak berlakunya Putusan Mahkamah Konstitusi tersebut salah satunya adalah Osman Sapta Odang, Osman sendiri merupakan ketua umum dari Partai Hanura yang sedang menjadi ketua DPD dan akan mencalonkan kembali menjadi calon anggota DPD. Osman Sapta Odang sebelumnya sudah masuk dalam Daftar Calon Sementara (DCS) namun dikarenakan ada Putusan Mahkamah Konstitusi tersebut akhirnya KPU merubah Peraturan KPU No 14 Tahun 2018 perihal pendaftaran Calon Perseorangan peserta Pemilu calon anggota DPD menjadi Peraturan KPU Nomor 26 Tahun 2018 yang memasukan syarat agar calon anggota DPD tidak dari unsur dari Parpol. Selain itu KPU Menerbitkan Keputusan KPU No 130/PL.01.4-Kpt/06/KPU/IX/2018 Tentang Penetapan Daftar Calon Tetap Perseorangan Peserta Pemilu Anggota Dewan Perwakilan Daerah Tahun 2019 tertanggal 20 September 2018 yang tidak memasukan Nama Osman Sapta Odang didalamnya karena Osman Sapta Odang tidak mengundurkan diri sebagai fungsionaris partai politik. Atas dasar tersbutlah terdapat protes dari kalangan DPD sendiri yaitu wakil ketua DPD Nono Sampono yang menyurati Komisi Pemilihan Umum (KPU) karena KPU mengikuti Putusan MK tersebut karena Putusan MK diputus di tengah masa pendaftaran calon peserta pemilu karena seharusnya Putusan Mahkamah Konstitusi tidak menimbulkan norma baru.

Jika melihat fakta tersebut keterkaitan antara asas Negative Legislator dengan Putusan Mahkamah Konstitusi Nomor 30/PUU-XVI/2018 maka belum dapat dikatakan Optimal karena MK masih sering mengeluarkan Putusan yang menimbulkan Norma baru dalam Putusannya sehingga berimbas kepada keberlakuan Putusan tersebut dalam masyarakat.

\section{E. Penerapan Asas Erga Omnes dan Asas Negative Legislator Pada Putusan Mahkamah Konstitusi Nomor 30/PUU-XVI/2018}

Osman Sapta Odang mengajukan gugatan keberatan atas Peraturan KPU Nomor 26 tahun 2018 ke BAWASLU karena dianggap KPU merubah peraturan 
KPU di tengah tengah proses pendaftaran calon anggota DPD. Namun keputusan sidang Ajudikasi Bawaslu pada tanggal 5 Oktober 2018 menolak gugatan Osman Sapta Odang yang menyebutkan KPU tidak melakukan pelanggaran administrasi karena menurutnya tindakan KPU sudah benar dengan mengikuti Putusan Mahkamah Konstitusi. Menurut penulis tindakan Bawaslu dengan tidak mengabulkan gugatan Osman Sapta Odang sudah tepat karena bagaimanapun juga Putusan Mahkamah Konstitusi tersebut harus di ikuti oleh setiap warga negara karena Putusan MK bersifat Final dan Mengikat sebagaimana yang tercantum pada Pasal 10 Undang-Undang MK.

Karena tidak puas dengan keputusan sidang Ajudikasi BAWASLU tersebut akhirnya sesuai dengan Pasall 469 Undang-Undangg No 7 Tahun 2017 tentang Pemilu, Osman Sapta Odang mengajukan upaya hukum ke Peradilan Tata Usaha Negara (PTUN). Keberatan Osman Sapta Odang yang di ajukan ke PTUN dikabulkan, dengan Putusan PTUN Nomor 242/G/SPPU/2018/PTUN.JKT dalam salah satu amar Putusannya PTUN menyatakan batal Keputusan KPU Nomor 130/PL.01.4-Kpt/06/KPU/IX/2018 perihal Penetapan Daftar Calon Tetap Perseorangan Peserta Pemilu Anggota Dewan Perwakilan Daerah Tahun 2019 tanggal 20 September 2018 dan juga meminta KPU untuk mengeluarkan keputusan perihal Penetapan Daftar Calon Tetap Perseorangan Peserta Pemilu Anggota Dewan Perwakilan Daerah Tahun 2019 yang memasukan nama Oesman Sapta sebagai Calon Tetap Perseorangan Peserta Pemilu Anggota Dewan Perwakilan Daerah Tahun 2019. ${ }^{9}$

Selain mengajukan keberatan ke PTUN Osman Sapta Odang juga mengajukan Uji Materil Peraturan KPU Nomor 26 Tahun 2018 ke Mahkamah Agung. Pada tanggal 25 Oktober 2018 Mahkamah Agung dalam Putusannya Nomor 65P/HUM/2018 mengabulkan permohonan Osman Sapta Odang dan membatalkan

\footnotetext{
${ }^{9}$ Peradilan Tata Usaha Negara Jakarta, Putusan Nomor 242/G/SPPU/2018/PTUN.JKT
} 
Peraturan KPU Nomor 26 tahun 2018 tersebut serta meminta KPU untuk memasukan Osman Sapta Odang pada Daftar Calon Tetap. ${ }^{10}$

Terjadinya pertentangan dan beda Putusan antara Mahkamah Konstitusi dan Mahkamah Agung serta Peradilan Tata Usaha Negara menunjukan lemahnya asas Erga Omnes yang melekat pada Putusan Mahkamah Konstitusi. Memang salah satu kewenangan dari Mahkamah Agung adalah menguji Peraturan di bawah Undang-Undang (termasuk juga Peraturan KPU) terhadap Undang-Undang namun ada baiknya Mahkamah Agung tetap mempertimbangkan Putusan Mahkamah Konstitusi yang merupakan sama dengan Undang-Undang. Karena menurut teori jenjang norma Undang-Undang berlaku sebagai Formel Gesetz sedangkan Peraturan KPU merupakan Autonome satzung dengan demikian seharusnya Mahkamah Agung dapat pula juga melihat Putusan Mahkamah Konstitusi sebagai kaidah yang sederajat dengan Undang-Undang. ${ }^{11}$

Jika hal tersebut dibiarkan maka akan ada potensi konflik karena adanya perbedaan putusan antara Mahkamah Konstitusi dengan badan peradilan lain yang memutus berbeda dengan Mahkamah Konstitusi, Disisi lain proses pemilihan calon anggota DPD masih terus berjalan. Jika melihat lebih jauh bahwa Putusan Mahkamah Agung memang tidak semuanya salah karena dasar pijakannya adalah Undang-Undang Nomor 12 Tahun 2011 tentang Pembentukan Peraturan Perundangg-Undangan namun hal tersebutt menurut hemat penulis adalah bagian dari mencari celah dari Osman Sapta Odang dalam rangka membatalkan Peraturan KPU Nomor 26 tahun 2018 yang merujuk dan mengikuti Putusan Mahkamah Konstitusi tersebut.

Dampak dari ketidak kuatannya penerapan asas erga Omnes ini berdampak pada sikap KPU dimana KPU akan sulit mengambil keputusan karena terdapat 2 putusan yang berbeda. Bila dikaitkan dengan asas Negative Legislator, Putusan

\footnotetext{
${ }^{10}$ Mahkamah Agung, Putusan Nomor 65P/HUM/2018

11 Maria Farida Indrati.S, Ilmu Perundang-Undangan jenis, fungsi dan materi muatan. (Yogyakarta: Penerbit Kanisius, 2007), hal . 18
} 
Mahkamah Konstitusi Nomor 30/PUU-XVI/2018 ini juga telah menabrak asas tersebut dengan mengatakan bahwa jika calon anggota DPD berasal dari Partai Politik maka hal tersebut dinyatakan in konstitusional dan tidak sesuai dengan Pasal 57 ayat (2a) yang akhirnya terdapat keberatan terhadap Putusan Mahkamah konstitusi tersebut yang di tuangkan dalam Peraturan KPU Nomor 26 Tahun 2018 tersebut.

Sebenarnya menurut hemat penulis Mahkamah Konstitusi memutus hal tersebut sudah benar namun, perlu di garis bawahi keterbatasan kewenangan MK yang di batasi oleh Undang-Undang MK itu sendiri akhirnya timbul lah paradigma bahwa Mahkamah Konstitusi tidak menjalankan Asas Negatif Legislator. Menurut Penulis, sebagai Lembaga Penegak Konstitusi Mahkamah Konstitusi haruslah di berikan kewenangan yang kuat dan tidak terbatas pada menentukan apakah Undang-Undang A quo bertentangan atau tidak dengan Undang-Undang Dasar 1945 saja. Pada Pasal 57 Undang-Undang MK terlihat jelas bahwa amar Putusan MK sangat dibatasi Pada Pasal 57 tersebut dan berimbas Putusan MK tidak komprehensif dan banyak di kritik oleh banyak kalangan serta tidak berlakunya asas erga Omnes dalam Putusan Mahkamah Konstitusi tersebut. Dalam hal Putusan Mahkamah Konstitusi Nommor 30/PUU-XVI/2018 penulis berpendapat setuju dengan Putusan Mahkamah Konstitusi dan menyayangkan Putusan MA dan PTUN tersebut karena Mahkamah Konstitusi sedang menjalankan perannya sebagai Guardian Of Constitution dimana menegakka Original Intent dari DPD bahwa DPD harus terbebas dari unsur Partai Politik. Terkait jatuhnya putusan MK di masa proses pendaftaran calon anggota DPD seharusnya para pihak bisa menerima putusan tersebut sebagai dasar bernegara dan dapat dijalankan putusan tersebut sehingga asas Erga Omnes dalam Putusan Mahkamah Konstitusi bisa berjalan.

Masalah dari tidak berjalannya asas tersebut adalah adanya klausul yang melarang anggota DPD berasal dari partai politik. Dalam hal ini Mahkamah Konstitusi sebagai lembaga negara penegak Konstitusi sudah benar melakukannya 
hanya saja karena Undang-Undang membatasi hanya dapat memutus sesuai dengan pasal 57 Undang-Undang MK maka banyak yang berpendapat bahwa MK Over lapping dari Kewenangannya.

\section{Penutup}

\section{A. Kesimpulan}

Berdasarkan kepada pembahasan pada bab sebelumnya, oleh karena itu disimpulkan sebagai berikut:

Mahkamah konstitusi adalah Lembaga negara yang mempunyai kekuasaan yang setara dengan Mahkamah Agung dalam melaksanakan kewenangan mengadili yang bebas. Mahkamah Konstitusi dibentuk agar menjadi penjaga konstitusi (Guardian of constitution) dimana agar produk hukum yang di buat (Undang-Undang) tetap sejalan dengan konstitusi. Mahkamah Konstitusi sebagai penjaga konstitusi diberi kewenangan mengadili untuk tingkat pertama serta terakhir dan putusannya bersifat final dan mengikat bagi seluruh rakyat Indonesia (erga omnes).

Pengujian yang dilakukan oleh Mahkamah Konstitusi terhadap Pasal 182 Huruf 1 Undang-Undang Nomor 7 Tahun 2017 tentang Pemilihan Umum ini menimbulkan penafsiran baru terhadap frasa "Pekerjaan lain" pada pasal tersebut. Mahkamah Konstitusi dalam Putusannya Nomor 30/PUU-XVI/2018 menafsirkan frasa "pekerjaan lain" pada Pasal 182 huruf 1 Undang-Undang Pemilu tersebut menjadi "tidak mempunyai kekuatan hukum mengikat secara bersyarat sepanjang tidak dimaknai mencakup pula pengurus (fungsionaris) Partai Politik". KPU merespon Putusan MK tersebut dengan mengubah Peraturan Komisi Pemilihan Umum Nomor 14 Tahun 2018 tentang pendaftaran calon perseorangan calon anggota DPD menjadi Peraturan KPU Nomor 26 Tahun 2018 yang memasukan syarat bahwa calon anggota DPD haruslah mengundurkan diri dari jabatannya sebagai fungsionaris partai Politik. Akibat adanya Putusan Mahkamah Konstitusi tersebut mengakibatkan bakal calon 
anggota DPD yang masih menjadi fungsionaris partai politik dipaksa mundur dari jabatannya di partai politik jika ingin tetap menjadi calon anggota DPD.

Terhadap Putusan Mahkamah Konstitusi yang di terapkan melalui Peraturan Komisi Pemilihan Umum nomor 26 Tahun 2018 tentang perubahan Peraturan Komisi Pemilihan Umum nomor 14 Tahun 2018 tentang pendaftaran calon perseorangan peserta pemilu calon anggota DPD terdapat pihak yang keberatan yaitu Osman Sapta Odang yang menggugat peraturan KPU tersebut ke Bawaslu dikarenakan Keputusan KPU diubah di tengah masa pendaftaran calon peserta pemilu. Bawaslu menolak gugatan bawaslu dengan alasan bahwa KPU sudah benar kaerena mengikuti Putusan MK Nomor 30/PUUXVI/2018 tersebut. Tidak puas dengan Keputusan Bawaslu tersebut maka Osman Sapta Odang mengajukan keberatan ke PTUN Jakarta. Pada Putusan PTUN Jakarta dengan Nomor Putusan 242/G/SPPU/2018/PTUN.JKT mengabulkan permohonan keberatan Osman Sapta Odang yang salah satu amarnya memerintahkan KPU untuk memasukan Osman Sapta Odang pada Daftar Calon Tetap (DCT). Selain mengajukan keberatan ke PTUN Jakarta Osman Sapta Odang juga melakukan Uji materil Peraturan KPU nomor 26 Tahun 2018 perihal perubahan Peraturan KPU nomor 14 Tahun 2018 tentang pendaftaran calon perseorangan peserta pemilu calon anggota DPD ke Mahkamah Agung. Senada dengan Putusan PTUN Jakarta, Putusan Mahkamah Agung dalam Putusannya Nomor 26/P/HUM/2018 mengabulkan permohonan Osman Sapta Odang dan menyatakan Peraturan KPU tidak mempunyai kekuatan hukum dan dibatalkan.

Putusan Mahkamah Agung dan PTUN Jakarta bertentangan dengan Putusan Mahkamah Konstitusi Nomor 30/PUU-XVI/2018 yang menyatakan bahwa calon anggota DPD haruslah bukan fungsionaris partai politik, sedangkan Osman Sapta Odang merupakan calon anggota DPD dan juga merupakan Ketua UMUM Partai Hanura. Atas dasar itu maka menurut pendapat penulis bahwa asas erga omnes yang melekat pada setiap Putusan 
MK tidak dijalankan dengan baik pada Putusan ini karena tidak semua masyarakat dapat menjalani Putusan Mahkamah Konstitusi tersebut.

Terkait dengan asas negative legislator maka penulis berpendapat juga bahwa Putusan Mahkamah Konstitusi ini melanggar asas ini. Mahkamah Konstitusi telah membuat penafsiran baru dalam suatu Undang-Undang sedangkan Mahkamah Konstitusi tidak diperbolehkan untuk membuat norma baru dan putusannya telah di atur dalam Pasal 57 Undang-Undang Mahkamah Konstitusi.

Terlepas dari asas negative legis lator dan erga omnes penulis berpendapat bahwa Putusan Mahkamah Konstitusi Nomor 30/PUU-XVI/2018 ini sudahlah benar karena Mahkamah Konstitusi ingin menjaga Original intent dari DPD itu sendiri dengan melarang fungsionaris partai Politik untuk menjadi calon anggota DPD. Namun Mahkamah Konstitusi di batasi oleh Undang-Undang MK yang menurut penulis kewenangan MK terlalu sempit dalam Undang-Undang tersebut yang hanya boleh memutus sesuai dengan yang sudah diatur dalam Pasal 57 Undang-Undangg MK

\section{B. Saran}

Selama masa penelitian, Penulis menemukan beberapa masukan yang perlu disampaikan agar dapat membenahi sistem hukum di Indonesia. Penulis berharap para pembuat undang-undang serta penegak hukum dapat dengan segera melakukan kajian ulang terhadap penerapan sanksi pidana bersyarat di Indonesia dikarenakan penerapat sanksi pidana bersyarat ini Penulis pandang kurang efektif apabila ditinjau dari segi pengawasan sehingga dapat menimbulkan perspektif negatif dari masyarakat umum terhadap putusan demikian.Selain itu pula, para penegak hukum dan pembuat undang-uindang diharapkan juga dapat segera mencari alternatif pemidanaan untuk menggantikan pidana bersyarat yang Penulis pandang sudah tidak efektif penerapannya. Demikian pula terhadap para hakim agar tidak menjatuhkan 
vonis tanpa mempertimbangkan peraturan perundang-undangan yang ada agar tidak menimbulkan ketidak pastian dalam penerapan hukum.

\section{Daftar Pustaka}

\section{A. Buku:}

Khelda, dan Abd Rais Aman. Hukum Tata Negara Indonesia (Jakarta: Mitra Wacana Media, 2006).

MD, Mahfud. Konstitusi dan Hukum dalam Kontroversi Isu (Jakarta: PT RajaGrafindo Persada, 2009).

S, Maria Farida I, Ilmu Perundang-Undangan jenis, fungsi dan materi muatan. (Yogyakarta: Penerbit Kanisius, 2007).

\section{B. Peraturan Perundang-undangan:}

Indonesia. Undang-undang Dasar Negara Republik Indonesia Tahun 1945. Undang-undang No 8 Tahun 2011 Tentang Perubahan Undangundang Nomor 24 Tahun 2003 Tentang Mahkamah Konstitusi ( Lembaran Negara Republik Indonesia Tahun 2011 Nomor 70, Tambahan Lembaran Negara Nomor 5226.

Undang-undang No 17 Tahun 2014 tentang MPR,DPR,DPD dan DPRD (Lembaran Negara Republik Indonesia Tahun 2018,Tambahan Lembaran Negara Nomor 29 Nomor 6187.

\section{Putusan}

Indonesia. Putusan Mahkamah Konstitusi Nomor 10/PUU-VI/2008

. Putusan Mahkamah Agung Nomor 65P/HUM/2018

\begin{tabular}{c} 
Putusan Peradilan Tata Usaha Negara Nomor \\
\hline 242/G/SPPU/2018/PTUN.JKT
\end{tabular}




\section{Internet}

Anonim, "5 Poin Penting dari Putusan MK larang pengurus parpol jadi anggota

DPD",

https://nasional.kompas.com/read/2018/07/24/08553721/5-poin-

penting-dari-putusan-mk-larang-pengurus-parpol-jadi-anggota-

dpd?page=all, tanggal 27 Juli 2018 pukul 09.36 WIB.

Anonim, "DPD Menyurati KPU bela Osman Sapta Odang", https://rumahpemilu.org/dpd-menyurati-kpu-bela-oesman-saptaodang, 25 September 2018 pukul 23.04 WIB.

Anonim, " Ratio Decidendi Dari Putusan MK yang memutuskan penyelenggaraan pemilu serentak padahal sebelumnya diputus sebaliknya",

http://repository.unair.ac.id/13750/13/13.\%20Bab\%203.pdf, 25 bulan September 2018 pukul 23.05.

Anonim, "dicoret dari daftar calon tetap oso gugat keputusan KPU", https://nasional.kompas.com/read/2018/09/20/20184821/dicoret-daridaftar-calon-tetap-oso-gugat-keputusan-kpu, 25 bulan September 2018 pukul 23.13. 